\title{
Politik Hukum Hak Cipta:Meletakkan Kepentingan Nasional Untuk Tujuan Global
}

\author{
Budi Agus Riswandi
}

\begin{abstract}
The logical consequences for Indonesia when it takes ratification on GATTWTO agreement in which it contains TRIPS agreement cause the disharmonization in the national law for intellectual copyright. One of law on copyright is the existence of law on copyright viewed political law perspective is still dominated by foreign interest. Whereas ideally, the law created nationally tends to bring the national interest. The national interest must be translated, in the frame of gaining its objective.
\end{abstract}

\section{Pendahuluan}

Peranan hukum dalam pembangunan ekonomi suatu bangsa merupakan sesuatu yang tidak dapat diabaikan keberadaannya. Sehingga sangat jelas, jika kondisi hukum suatu bangsa itu efektif, maka pembangunan ekonomi pun akan mudah untuk dilaksanakan. Namun, sebaliknya jika hukum tidak memampu berperan secara efektif, maka dapat dipastikan akan berdampak buruk terhadap pembangunan ekonomi.

Kondisi ini tentu berlaku pula bagi Indonesia sebagai sebuah negara yang sedang giat-giatnya melakukan pembangunan ekonomi. Apalagi, tatkala Indonesia menyatakan diri dalam konstitusinya sebagai negara hukum (rechtstaat). Dari sini tersirat pula bahwa Indonesia menghendaki dua hal; Pertama, hukum diharapkan dapat berfungsi; Kedua, dengan hukum dapat berfungsi, maka pembangunan ekonomi pun akan mudah untuk direalisasikan.

Sejalan dengan pemikiran ini, kalau dikaji dari sisi politik hukum acapkali pembentukan hukum, khususnya hukum ekonomi tak selalu sinkron dengan harapan-harapan tersebut. Sebagai faktor yang menjadi pemicu tidak adanya kesinkronan ini karena banyak kepentingan yang berkembang diseputar pembentukan hukum. Kasus riil yang terjadi adalah dalam pembentukan hukum Hak Cipta. Politik hukum yang berkembang berupa adanya tarik menarik antara kepentingan nasional dan asing. Alhasil, hukum yang dapat dijadikan sarana bagi pembangunan ekonomi nampaknya menjadi sia-sia karena yang dikedepankan justru kepentingan asing yang dominan.

Oleh karena itu, penting dipahami bagian 
yang mana semestinya segera dilakukan pembentukan hukum hak cipta guna merubah orientasi dari hukum hak cipta itu sendiri agar lebih banyak memiliki dimensi kepentingan nasional. Berikut dalam artikel ini akan dicoba dikemukakan beberapa analisis terhadap permasalahan tersebut.

\section{TRIPs sebagai "Sumber Hukum Nasional" dalam UU Hak Cipta}

Globalisasi ekonomi akhirnya berimbas juga pada globalisasi hukum. Hal ini dapat diruntut salah satunya melalui keikutsertaan Indonesia terhadap forum GATTNTO. Perlu diketahui ketika Indonesia meratifikasi Persetujuan Pendirian Organisasi Perdagangan Dunia (Agreement Establishing the World Trade Organization) melalui UU No. 7 Tahun 1994, maka seketika itu pula Indonesia sudah masuk kepada apa yang disebut dengan "globalisasi". Globalisasi di sini menurut Antonio Giden dalam bukunya The Runway World merupakan globalisasi yang masuk pada setiap aspek kehiduapan manusia, baik ekonomi, politik bahkan sampai budaya.

Dari sisi hukum tentu keikutsertaan indonesia dalam forum GATT/WTO akhirnya melahirkan istilah yang disebut "Globalisasi Hukum". Betapa tidak dengan Indonesia meratifikasi Persetujuan Pendirian Organisasi Perdagangan Dunia beserta lampirannya hal ini berarti Indonesia wajib dan harus komit terhadap pelaksanaan GATT/WTO sendiri. Komitmen Indonesia diwujudkan dalam bentuk melakukan upaya harmonisasi hukum nasional dengan hukum internasional yang ada dalam forum GATTMTO.

Persetujuan WTO (WTO Agreement), termasuk di dalamnya Persetujuan mengenai Pembentukan WTO, mencakup; a) persetujuan multilateral di bidang perdagangan barang (populer dengan sebutan GATT 1994, yang terdiri dari berbagai teks persetujuan; b) persetujuan umum di bidang perdagangan jasa (General Agreement on Trade in Sevices $=$ GATS); c) persetujuan mengenai perdagangan dalam kaitannya dengan aspek hak atas kekayaan intelektual (Agreement on Trade Related Aspects of Intellectual Property Rights = TRIPS); d) kesepakatan mengenai tata tertib aturan dan prosedur penyelesaian sengketa (Understanding on Rules and Prosedures Governing the Settlement of Disputes = DSB); e) kesepakatan mengenaj. mekanisme peninjauan kembali kebijaksanaan perdagangan (Trade Policy Review Mechanism = TPRM); dan f) persetujuan perdagangan plurilateral (Plurilateral Trade Agreement $=$ PTAs). GATT 1994, GATS, TRIPs, DSU dan TPRM disebut persetujuan perdagangan multilateral (Multilateral Trade Agreement $=$ MTAs). Perlu dicatat bahwa sampai saat ini indonesia belum menandatangani PTAs (mencakup persetujuan-persetujuan mengenai Civil Aircraft, Government Procurement, Dairy Product, dan Bovine Meat). Dengan demikian, Indonesia tidak mempunyai kewajiban apapun terhadap PTAs. ${ }^{1}$

Khusus berkaitan dengan pembentukan

'Hartanto Reksodipoetro, "Peluang dan Tantangan Pasca Putaran Unuguay: Kesiapan Indonesia dalam Perdagangan Internasional, "Disampaikan pada Seminar Nasional WTO, Mekanisme Perdagangan Intemasional Antara Peluang dan Tantangan, Serta Kesiapan Indonesia," (Fakultas Hukum Atma Jaya, Yogyakarta, 1 Maret 1997). 
UU Hak Ciptạ aspek persetujuan internasional yang dituangkan dalam TRIPs ${ }^{2}$ mengikat untuk diharmonisasi dalam UU Hak Cipta. Melalui proses semacam ini kesan yang muncul bahwa UU Hak Cipta sebenarnya dibentuk berdasarkan pada sumber hukum yang berbeda dari sumber hukum biasanya. ${ }^{3}$

$\mathrm{Hal}$ yang dapat dibenarkan bahwa pembentukan UU Hak Cipta tidak sematamata langsung mendasarkan diri pada ketentuan TRIPs, namun melandaskan diri UU No. 7 Tahun 1994 tentang Pengesahan Agreement Establishing the World Trade Organization, namun UU ini sendiri sebenarnya jika dilihat dari ketentuannya hanya sifatnya mengesahkan. Dalam Ketentuan Pasal 1 UU No. 7 Tahun 1994 dinyatakan:

Mengesahkan Agreement Establishing The World Trade Organization (Persetujuan Pembentukan Organisasi Perdagangan Dunia) beserta lampiran 1,2,3 Persetujuan tersebut, yang salinan naskah aslinya dalam bahasa Inggris serta terjemahannya dalam bahasa Indonesia dilampirkan, sebagai bagian yang tidak terpisahkan dari UndangUndang ini.
Berdasar pada ketentuan Pasal 1 terlihat UU No. 7 Tahun 1994 hanya bersifat formalitas, sedangkan dari sisi substansi sebenarnya muatannya ada pada hasil-hasil Persetujuan Pembentukan Organisasi Perdagangan Dunia, termasuk di dalamnya mengenai masalah TRIPs. TRIPs Agreement pada dasarnya menerapkan standar minimum (minimum standards) bagi semua anggota WTO. Hal ini terlihat secara jelas dalam Article 1 dari TRIPs Agreement yang berbunyi: "Members shall give effect to the provisions of this Agreement. Members may, but shall not be obliged to, implement in their law more extensive protection than is required by this Agreement, provided that such protection does not contravene the provisions of this Agreement. Members shall be free to determine the appropriate method of implementing the provisions of this Agreement within their own legal system and practice."

Dari bunyi article 1 dapat diketahui bahwa TRIPs menghendaki adanya perlindungan hukum terhadap hak kekayaan intelektual (hak cipta) lebih tinggi. Akan tetapi, dalam waktu

${ }^{2}$ Masalah TRIPs (Trade Related Intellectual Property Rights) menjadi penting, karena faktor-faktor yang dapat mempengaruhi perdagangan internasional telah berkembang semakin kompleks dan bervariasi, sejalan dengan perkembangan teknologi yang sangat pesat. Perlindungan dan penggunaan IPR menjadi unsur yang utama dalam persaingan perdagangan internasional. Negara-negara Pemrakarsa Putaran Uruguay mengemukakan alasan bahwa banyak perusahaan telah melakukan counterfeiting yang dapat merusak kepentingan produsen dan konsumen produk sejenis. Hal ini merupakan bukti tidak memadai dan tidak efektifnya pengaturan IPR yang ada diadministrasi oleh WIPO. Lihat Taryana Soenandar, Perlindungan Hak Milik Intelektual di Negara-Negara ASEAN (Jakarta: Sinar Grafika, 1996), hlm.11. Selanjutnya, pembahasan menigenai perlindungan hak cipta pasca persetujuan TRIPs dapat dilihat pada Rahmi Jened, Perlindungan Hak Cipta Pasca Persetujuan TRIPs (Surabaya: Yuridika Press, 2001).

${ }^{3}$ Seperti diketahui dalam hierarkis peraturan perundang-undangan, khususnya TAP MPR No. III/MPR 2000 bahwa undang-undang berada di bawah Ketatapan MPR dan UUD 1945. Oleh karena itu, undangundang yang dibentuk selain tidak boleh bertentangan dengan ketentuan di atasnya, juga harus mengacu kepada peraturan di atasnya, yakni ketetapan MPR dan UUD 1945. 
bersamaan TRIPs juga membolehkan setiap negara untuk memperluas ruang lingkup perlindungan pada hal-hal yang baru yang belum ada di dalam persetujuan, seperti kepemilikan local dan kebudayaan masyarakat tradisional. ${ }^{4}$

\section{Arti Penting Politik Hukum dalam Peletakan Kepentingan Nasional}

Kehadiran hukum dalam masyarakat di antaranya adalah untuk mengintegrasikan dan mengkoordinasikan kepentingankepentingan yang bisa bertubrukan satu sama lain itu oleh hukum diintegrasikan sedemikian rupa sehingga tubrukan-tubrukan itu bisa ditekan sekecil-kecilnya. Pengorganisasian kepentingan-kepentingan itu dilakukan dengan membatasi dan melindungi kepentingan-kepentingan tersebut. Memang, dalam suatu lalu lintas kepentingan, perlindungan terhadap kepentingankepentingan tertentu hanya dapat dilakukan dengan cara membatasi kepentingan di lain pihak. $^{5}$

Hukum melindungi kepentingan seseorang dengan cara mengalokasikan suatu kekuasaan kepadanya untuk bertindak dalam rangka kepentingannya tersebut. Pengalokasian kekuasaan ini dilakukan secara terukur, dalam arti ditentukan keluasan dan kedalamannya. Kekuasaan yang demikian itulah yang disebut hak. Dengan demikian, tidak setiap kekuasaan dalam masyarakat itu bisa disebut sebagai hak melainkan hanya kekuasaan tertentu saja, yaitu yang diberikan oleh hukum kepada seseorang. ${ }^{6}$

Dalam konteks kepentingan antar negara, maka kepentingan itu dapat direpresentasikan dalam batasan mencegah ancaman dari pihak Juar. Penyelamatan negara dari ancaman dalam dan luar adalah merupakan hak dan kewajiban setiap negara dan bersifat universal. Hak dan kewajiban setiap negara untuk menegakkan kedaulatannya harus tetap dalam batas-batas rambu yang diperbolehkan oleh ketentuan perundang-undangan. Hal terakhir ini juga bersifat universal karena dapat dikatakan bahwa tidak ada satupun negara yang tidak memiliki ketentuan peraturan perundang-undangan tentang bagaimana negara itu menyelamatkan dan melindungi wilayahnya, penduduknya dan kekayaannya. Konstitusi setiap negara sudah pasti menegaskan tentang hak, kewajiban, tugas, wewenang dan tanggung jawab baik negara maupun penduduknya untuk mempertahankan atau menyelamatkan negara?

Dari pemikiran ini, maka merupakan suatu keharusan bagi suatu negara tatkala merumuskan suatu peraturan perundangundangnya senantiasa memperhatikan pada

${ }^{4}$ Carlos M Correa, Intellectual Property Rights, the WTO and Developing Countries the TRIPs Agreement and Policy Options (London and New York: Zed Books Ltd, 2000), hlm.9.

${ }^{5}$ Sartijpto Raharjo, IImu Hukum (Bandung: Alumni, 1982), hIm. 64.

${ }^{B}$ Ibid.

${ }^{7}$ Romli Atmasasmita, Reformasi Hukum, Hak Asasi Manusia dan Penegakan Hukum (Bandung: Mandar Maju, 200), hlm. 194. 
aspek kepentingan nasional (national interests). Untuk dapat mencapai hal demikian, maka faktor politik hukum akan sangat menentukan. Bagi beberapa negara pola pemikiran ini menjadi sarana yang cukup efektif. Sebagai contoh dari pernyataan ini misalnya dalam kasus civil disorder Pemerintah Australia telah mengaturnya dalam Defence Act 1993. Di sini sikap Pemerintah Australia melindungi negaranya dalam. keadaan apapun termasuk keadaan yang disebut dengan civil disorder. ${ }^{8}$

Akan tetapi sebaliknya di Indonesia, fenomena ini tidak dapat ditemukan. Keberadaan peraturan perundang-undangan hanya sebatas aturan normatif yang kering dengan semangat kepentingan nasional. Kalaupun, Indonesia mempunyai peraturan perundang-undangan yang menonjol justru . semangat kepentingan negara-negara di luar (baca: negara-negara maju). Hal ini dapat dirasakan terutama terkait dengan aturan hukum ekonomi.

Berangkat dari persoalan ini, maka sesungguhnya peranan politik hukum dalam konteks hukum sangat memegang peranan yang sangat strategis. Barangkali melalui pendekatan politik hukum, maka hukum yang dibentuk pun setidaknya akan banyak memperhatikan kepada' kepentingan nasional. Pengertian kepentingan nasional bukan berarti dimaknai dalam arti yang sempit, namun kepentingan nasional di sini merupakan titik tolak dalam upaya mamasuki dunia global.

\section{Politik Hukum Hak Cipta: Meletakkan Kepentingan Nasional untuk Tujuan Global}

Kebijakan pembangunan ekonomi negara-negara berkembang telah berubah secara drastis sejak tahun 1980-an. Hampir semua negara berkembang menggeser kebijakan-kebijakan ekonomi mereka ke arah liberalisasi yang lebih besar dan kepercayaan yang lebih besar pada mekanisme pasar melalui serangkaian reformasi ekonomi berorientasi pasar. Nyaris di segala penjuru dunia, negara-negara berkembang mulai mengadopsi kebijakan-kebijakan yang dimaksudkan untuk merestrukturisasi watak peran negara dalam perekonomian, untuk meliberalisasi perdagangan domestik dan regulasi invenstasi dan untuk menswastakan perusahaan-perusahaan milik negara. Berbagai reformasi kebijakan tersebut nyaris menggantikan secara keseluruhan semua kebijakan sebelumnya yang mendominasi negara-negara berkembang dari tahun 1950an hingga 1970-an-reformasi yang mengenyahkan nasionalisme ekonomi dari perbendaharaan kata negara-negara itu, mengurangi peran eksesif negara dalam perekonomian, dan menghentikan kecenderungan pada pembangunan di Dunia Ketiga didasarkan pada premis kebijakankebijakan memandang keluar, dirancang untuk mengintegrasikan perekonomian ke dalam pasar global, utamanya ketika strategistrategi berorientasi ekspor mengganitikan industrialisasi susbstitusi impor. ${ }^{9}$

\section{s/bid.}

${ }^{9}$ Muhadi Sugiono, Kritik Antonio Gramsci Terhadap Pembangunan Dunia Ketiga, Yogyakarta: Pustaka Pelajar, 1999, hlm. Xii. Paul Hirst dan Grahame Thompson dalam bukunya yang berjudul Globalisasi Adalah Mitos menyimpulkan problem-problem disekitar dalil globalisasi, yakni; Pertama, bahwa hanya sedikit eksponen 
Untuk mendukung proses pengintegrasian ekonomi secara global, maka hukum pun diposisikan dalam kerangka mendukung tujuan besar tersebut. Salah satu hukum yang diorentasikan pada hal itu misalnya hukum dalam bidang hak kekayaan intelektual. Fenomena ini sebenarnya kalau dicermati secara mendalam lagi bukanlah semata-mata dalam upaya pembentukan globalisasi ekonomi, namun tidak lebih sebagai upaya mengukuhkan kepentingan ekonomi dari negara-negara maju. Berlandaskan pada pemahaman ini, maka pembentukan hukum hak kekayaan intelektual yang berbasis pada kesepakatan TRIPs dapat saja dimaknai sebagai wujud dominasi kepentingan negara maju terhadap negara berkembang.

Oleh karena itu, untuk mengantisipasi adanya "ekspolitasi" ekonomi dari negara maju terhadap negara berkembang (baca: Indonesia) semestinya dalam upaya melakukan harmonisasi hukum dari TRIPs terhadap UU
Hak Cipta ini pemerintah (Presiden dan DPR) meletakkannya dalam kerangka kepentingan nasional. ${ }^{10}$

Dari prinsip kepentingan nasional ini, maka pemerintah diajak untuk mengambil langkah strategis dan jitu dalam upaya meraup manfaat ekonomi dari HKI dan manfaat ekonomi tersebut dapat dirasakan oleh bangsa Indonesia sendiri bukan malah sebaliknya bangsa lain yang menikmati hasil dari pembentukan hukum tersebut.

Konsep ini, sebenarnya kalau dicermati masih sangat terbuka untuk dilakukan oleh pemerintah. Semisal dalam Pasal 10 UU Hak Cipta dinyatakan:

(1). Negara memegang Hak Cipta atas karya peninggalan prasejarah, sejarah dan benda budaya nasional lainnya.

(2). Negara memegang Hak Cipta atas folklor dan hasil kebudayaan rakyat yang menjadi milik bersama, seperti cerita, hikayat, dongeng, legenda, babad, lagu, kerajinan tangan, koreografi, tarian, kaligrafi, dan karya seni lainnya.

globalisasi yang mengembangkan konsep yang secara logis berkaitan mengenai perekonomian dunia di mana kekuatan supra-nasional dan pelaku-pelakunya bersifat menentukan; Kedua, bahwa dengan menunjukkan fakta tentang meluasnya internasionalisasi hubungan ekonomi sejak tahun 1970-an, itu sendiri tidak membuktikan munculnya struktur ekonomi global yang berbeda; Ketiga, bahwa perekonomian internasional tunduk kepada perubahan struktural yang besar di dalam abad lalu dan bahwa sudah ada periode lebih awal internasionalisasi perdagangan, anus modal dan sistem moneter, khususnya antara tahun 1870-1914; Keempat, bahwa TNC yang benar-benar global hanya relatif sedikit dan bahwa kebanyakan perusahaan multinasional terus beroperasi dari basis nasional yang berbeda-beda; dan Kelima, bahwa prospek regulasi oleh kerjasama internasional, pembentukan blok-blok perdagangan, dan berkembangnya strategi-strategi nasional baru yang memperhatikan intemasionalisasi sama sekali belum habis. Paul Hirst dan Grahame Thompson, Globalisasi Adalah Mitos (Jakarta: Yayasan Obor, 2001), hlm. 300-301 Lihat juga George Soros, Krisis Kapitalisme Global (Yogyakarta: Al-Qalam, 2002).

${ }^{10} \mathrm{Kebijakan}$ pemerintah saat ini baru sebatas penguatan pada instrumen hukum. Hal ini dapat dilihat dari lima langkah strategis yang diambil oleh pemerintah, yakni legislasi dan konvensi internasional, administrasi, kerjasama, kesadaran masyarakat dan penegakan hukum. Zein Umar Purba, "Pokok-Pokok Kebijakan Pembangunan Sistem HaKI Nasional," Jumal Hukum Bisnis Volume 13 April 2001, hlm. 4-5. 
(3). Untuk mengumumkan atau memperbanyak Ciptaan tersebut pada ayat (2), orang yang bukan warga negara Indonesia harus terlebih dahulu mendapat izin dari instansi yang terkait dalam masalah tersebut.

(4). Ketentuan lebih lanjut mengenai Hak Cipta yang dipegang oleh Negara sebagaimana dimaksud dalam Pasal ini, diatur dengan Peraturan Pemerintah.

Dari ketentuan Pasal 10 UU Hak Cipta sangat jelas bahwa aturan ini mempunyai arti yang strategis dan sekaligus mengandung potensi ekonomi yang sangat tinggi bagi bangsa Indonesia. Seperti diketahui bangsa Indonesia dalam kenyataannya mempunyai banyak potensi karya dari hasil kebudayaan masyarakat. Dengan kenyataan itu, sudah sewajarnya apabila pemerintah orentasi politik hukum lebih mengedepankan pembentukan instrumen-instrumen hukum yang terkait dengan permasalahan ini.

Akan tetapi hal ini sangat disayangkan mengingat pemerintah nampaknya kurang peka atas kebutuhan ini. Akibatnya sangat jelas bangsa Indonesia banyak sekali dirugikan baik secara ekonomi maupun moral. Contoh kasus adanya pelanggaran motif batik di negara Malaysia yang mana batik ini sebenarnya merupakan karya dari masyarakat Tamansari Yogyakarta.

Hal serupa yang sebenarnya masih terbuka juga bagi pemerintah untuk melakukan hal yang sama seperti di atas. Hal ini terkait dengan peluang kepada pemerintah untuk melakukan pembentukan aturan hukum yang terkait dengan masalah lisensi wajib. Tentunya, pembentukan hukum ini tidak semata-mata sebatas dituangkan dalam UU Hak Cipta namun hendaknya dituntaskan hingga kepada peraturan pelaksananya. Bagaimana pun keberadaan aturan hukum yang mengatur lisensi wajib dalam prakteknya akan sangat bermanfaat bagi proses pencerdasan kehidupan bangsa, terutama menyangkut akses terhadap ilmu pengetahuan bagi seluruh komponen bangsa. Dengan dikuasainya ilmu pengetahuan, maka harus diyakini bahwa pertumbuhan ekonomi akan dapat direalisasi.

Hal ini setidaknya tergambar dalam diagram yang dikemukakan oleh J. Davidson Frame yang memandang bahwa ilmu pengetahuan merupakan landasan awal dalam membangun pertumbuhan ilmu pengetahuan. Diagram yang dimaksud adalah: ${ }^{11}$

Science $\Rightarrow$ Technology $\Rightarrow$ Productivity $\Rightarrow$ Economicgrowth.

Dari diagram di atas, nampak jelas bahwa dengan ilmu pengetahuan para ilmuwan akan mengaplikasikannya dalam bentuk teknologi, di mana teknologi ini akan menciptakan produktifitas dan muaranya dengan tingkat produktifitas yang tinggi pertumbuhan ekonomi suatu bangsa akan dapat diraih dengan maksimal.

Berdasarkan argumentasi itulah, maka peletakan hukum yang mengatur lisensi wajib menjadi sangat penting. Orientasi akhir dari pembentukan dasar hukum yang tuntas dari lisensi wajib ini, pada akhirnya hukum mampu

"J. Davidson Frame, International Business and Global Technology, Toronto: LexingtonBooks, 1983, hlm.8. 
diletakkan pada kepentingan nasional dalam kerangka menyongsong era globalisasi.

Selanjutnya, masih terkait dengan politik hukum hak cipta akan sangat pantas bila pengaturan sanksi pidana yang ada dalam UU Hak Cipta tidak didasarkan pada model delik biasa. Delik biasa mengandung arti bahwa setiap perbuatan pidana dalam bidang hak cipta akan ditegakkan tanpa harus menunggu pengaduan dari pihak yang dirugikan. Penyidik dapat langsung melakukan tindakan hukum kepada pelanggar hukum hak cipta.

Sebagaimana diketahui praktek pembajakan di Indonesia hingga kini masih sangat marak. Anggapan ini setidaknya didasarkan pada data yang dikeluarkan oleh IDC pada awal tahun 2004 yang menyatakan ada tiga negara yang kategori mempunyai tingkat pembajakan yang sangat tinggi. Negara-negara itu yakni; Vietnam (95\%), Cina $(92 \%)$ dan Indonesia (89\%). Di sini terlihat Indonesia menduduki urutan nomor tiga dalam hal pembajakan hak cipta. Hal yang tidak dapat dipungkiri pelaku dari pembajakan itu sendiri pada dasarnya masih sangat dominan dari kalangan bangsa Indonesia. ${ }^{12}$

Berdasarkan realitas ini, maka penerapan delik biasa akan sangat menjadi "bumerang" bagi bangsa Indonesia sendiri. Artinya aturan itu sebenarnya tidak memberikan pengaruh yang sangat besar terhadap proses penegakan hukum hak cipta. Justru yang timbul di lapangan muncul bentuk penyimpangan baru terkait dengan penerapan delik aduan ini. Penyimpangan tersebut wujudnya bahwa penegakan hukum hak cipta khususnya dalam penerapan delik biasa ini ada kecenderungan bersifat transaksional. Proses inilah kiranya yang dianggap tidak memberikan nilai manfaat bagi kepentingan bangsa secara keseluruhan.

\section{Simpulan}

Pembentuan hukum hak cipta pada hakekatnya tidak dapat melepaskan diri dari aspek politik hukum. Kenyataannya, kalau dianalisis hukum hak cipta yang terbentuk sekarang lebih mencerminkan pada kepentingan asing. Untuk hal ini, maka perlu dilakukan suatu pendekatan baru dengan menggunakan pendekatan politik hukum juga, dimana politik hukum ini lebih diarahkan pada politik hukum yang berbasis kepada kepentingan nasional untuk tujuan global. Beberapa aspek yang penting - untuk diperhatikan dalam kaitannya dengan cara pendekatan ini dalam bidang hukum hak cipta meliputi, aspek kebudayaan milik masyarakat, lisensi wajib dan penerapan delik biasa.

\section{Daftar Pustaka}

Atmasasmita, Romli, Reformasi Hukum, Hak Asasi Manusia dan Penegakan Hukum, Bandung: Mandar Maju, 2001.

Correa, Carlos M, Intellectual Property Rights, the WTO and Developing Countries the TRIPs Agreement and Policy Options, London and New York: Zed Books Ltd, 2000.

Frame, J. Davidson, International Business

${ }^{12}$ Budi Agus Riswandi, "E-Commerce dan Regim Hak Kekayaan Intelektual," Majalah Legal Review, 31 Maret-30 Maret 2004/No. 19/Th Il, hlm. 31. 
and Global Technology, Toronto: LexingtonBooks, 1983.

Hirst, Paul dan Grahame Thompson, Globalisasi Adalah Mitos, Jakarta: Yayasan Obor, 2001.

Perlindungan, Rahmi Jened, Hak Cipta Pasca Persetujuan TRIPs, Surabaya: Yuridika Press, 2001.

Purba, Zein Umar, "Pokok-Pokok Kebijakan Pembangunan Sistem HaKI Nasional," Jumal Hukum Bisnis Volume 13 April 2001.

Raharjo, Sartjipto, IImu Hukum, Bandung: alumni; 1982.

Reksodipoetro, Hartanto, "Peluang dan Tantangan Pasca Putaran Uruguay: Kesiapan Indonesia dalam Perdagangan Internasional,"
Disampaikan pada Seminar Nasional WTO, Mekanisme Perdagangan Internasional Antara Peluang dan Tantangan, Serta Kesiapan Indonesia," Fakultas Hukum Atma Jaya Yogyakarta, Yogyakarta, 1 Maret 1997.

Riswandi, Budi Agus, "E-Commerce dan Regim Hak Kekayaan Intelektual," Majalah Legal Review, 31 Maret-30 Maret 2004/No. 19/Th II.

Soenandar, Taryana, Perlindungan Hak Milik Intelektual di Negara-Negara ASEAN, Jakarta: Sinar Grafika, 1996.

Soros, George, Krisis Kapitalisme Global, Yogyakarta: Al-Qalam, 2002.

Sugiono, Muhadi, Kritik Antonio Gramsci Terhadap Pembangunan Dunia Ketiga, Yogyakarta: Pustaka Pelajar, 1999, 